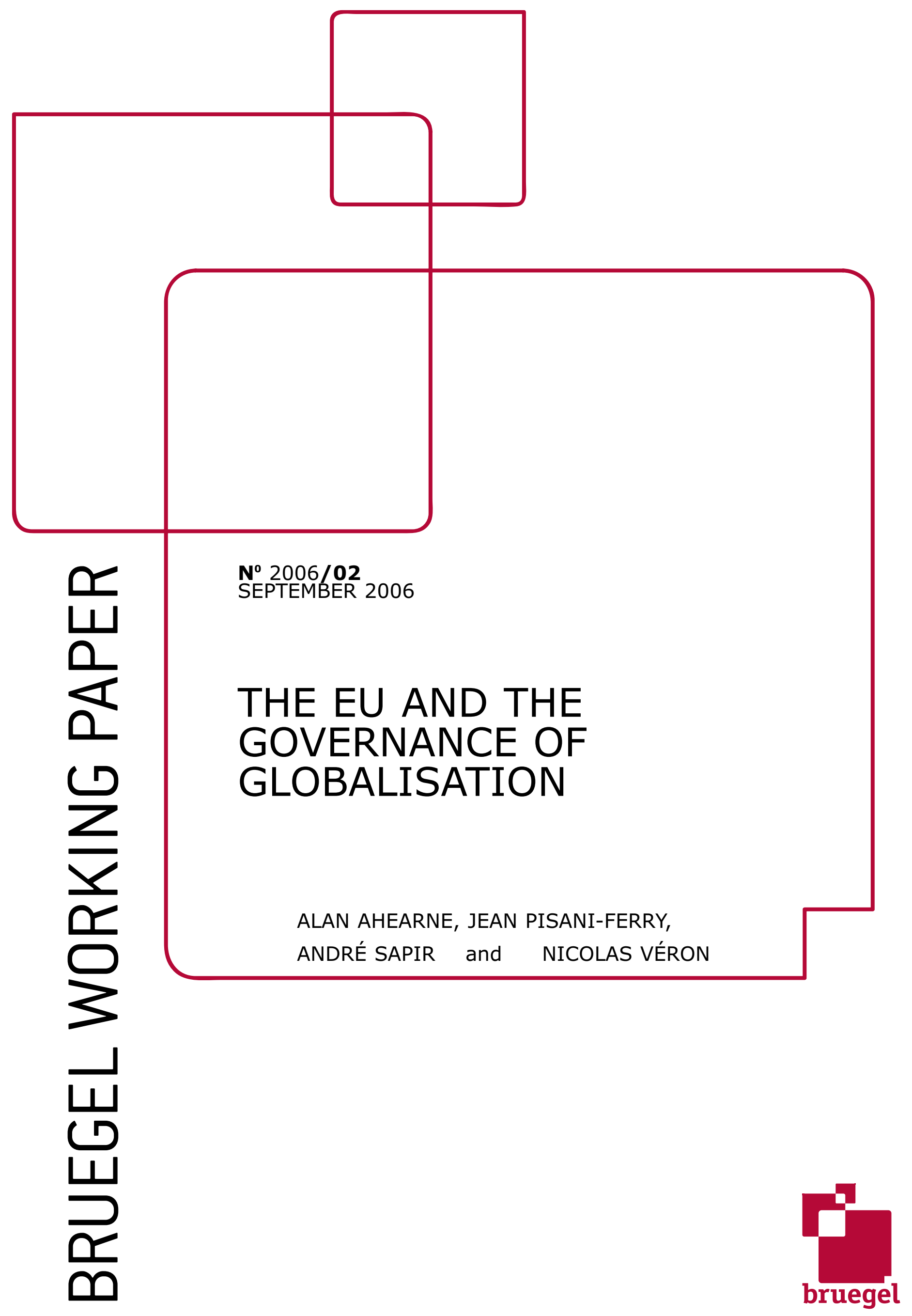



20 September 2006

Alan Ahearne, Jean Pisani-Ferry, André Sapir and Nicolas Véron ${ }^{1}$

\section{The EU and the Governance of Globalisation}

This paper is a contribution to the project Globalisation Challenges for Europe and Finland organised by the Secretariat of the Economic Council. The project is a part of Finland's EU Presidency programme and its objective is to add momentum to the discussion in the European Union on globalisation, Europe's competitiveness policy and the Lisbon strategy.

1 The authors (Bruegel, Brussels) are especially grateful to Sixten Korkman and Richard Baldwin for comments on an earlier draft, and they thank Jérémie Cohen-Setton for excellent research assistance. 



\section{Contents}

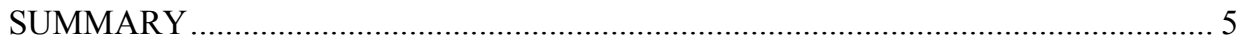

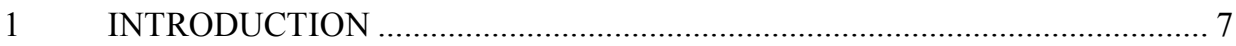

2 THE MALAISE ABOUT GLOBAL GOVERNANCE ……………...................... 8

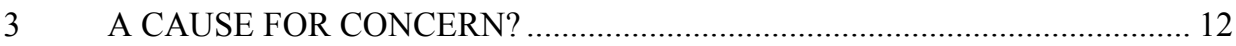

4 THE EU AND GLOBAL GOVERNANCE …………....................................... 20

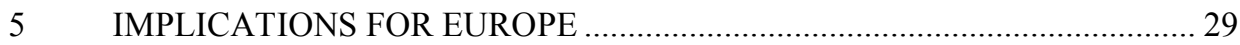

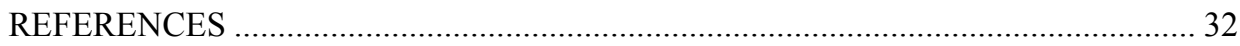





\section{SUMMARY}

The system of multilateral rules and institutions that constitutes the global economic governance regime trails the rapid transformation of the world economy and the rise of pressing global issues. It faces significant challenges such as the resurgence of economic nationalism. It needs to adapt to changes in the geopolitical background and to a growing number and diversity of participants in global economic integration. It must learn to coexist with regionalism and the market-led governance.

It is possible for globalisation to proceed with weak global governance, but not without significant risks to its sustainability. The EU, which has a stake in the multilateral system and most likely a comparative advantage in institutional design, should be a key player in its reform agenda. The difficulty of the task is no excuse for avoiding it and for hiding behind US leadership. To equip itself with the ability to take initiatives towards reform, the EU requires changes in its own internal governance and its external representation. Contrary to conventional wisdom, these changes need not imply a federalisation of external relations. 



\section{INTRODUCTION}

It is hard to escape the impression that global economic governance trails the rapid transformation of the world economy and the rise of pressing new issues. The suspension of global trade negotiations in July 2006 highlights the difficulty of delivering on the multilateral front and is bound to give further impetus to the proliferation of regional trade agreements. The two global institutions long seen as most effective, the International Monetary Fund (IMF) and the World Bank, have lost relevance. The IMF's core business of conditional financial assistance is threatened by Asian disaffection and Latin American detachment, and its attempted resurrection as a venue for managing global current account imbalances is a high-risk gamble. The World Bank has already been to a large extent crowded out from project lending by the development of financial markets.

At the same time, mounting issues remain unresolved. The labour market consequences of globalisation are a cause for concern in almost all countries, but the International Labour Organisation is as marginal as ever. Population is on the rise in some of the poorer regions on Earth and a new wave of migrations has started, but the International Organisation on Migrations remains almost unnoticed. Almost ten years after it was signed, the Kyoto protocol on global warming is still rejected by the US and major developing economies, and even those countries that support it frequently make insufficient efforts to enforce it at home. In addition, the shifting supply and demand patterns for fossil fuels, water and other natural resources create scope for new tensions, but no meaningful international response has emerged to establish properfunctioning markets and avert the risk of conflict.

To be sure, there are certainly some brighter spots. The Bank for International Settlements (BIS), the oldest multilateral institution, is a valuable venue for joint initiatives and dialogue between central banks. More generally, cooperation between technical and sector-specific agencies is frequently effective. However, there is a clear contrast between the rapid pace of market-led integration and slow institutional developments at the multilateral level.

This situation raises major, perhaps unprecedented policy challenges. Yet the balance of economic and political power makes addressing these challenges more difficult than at any time in recent decades. Global economic governance was a stable and relatively simple game in a Western hemisphere under US leadership. It is made much more unstable and complex by the rise in the number and diversity of players, the growing weight of new economic powers, increasing US scepticism about 'foreign entanglements', and Europe's continued focus on its own internal integration. 
How Europeans should respond to these challenges is a difficult question, and they tend to have mixed feelings. On the one hand, they see themselves as supporters of strong global rules and effective international institutions, and are more comfortable than others with the implied limitations to sovereignty. Having established a system of supranational governance at the regional level, Europeans tend to see global governance as a natural extension, and regard the EU as a laboratory for what the world of tomorrow could look like. On the other hand, they remain reluctant to exercise leadership and initiate reform. Even though the EU has been enterprising on trade and global warming, its actual policy record in those fields is mixed at best). It has generally been a follower on financial matters, its actions on development assistance are inconsistent, and it is divided on many issues such as migration. Furthermore, the EU's own complex governance system raises issues of internal consensus-building and external representation that frequently prevent Europeans from taking initiatives.

This raises significant strategic questions for Europe. First, is the sorry state of global governance a cause for serious concern or can it persist without much damage? After all, whatever the travail of international negotiations, world growth is currently more buoyant than ever and concrete economic integration continues at a rapid pace. Second, assuming the global regime is in need of change, should the EU aim at taking initiatives in the reform process or should it remain a follower? Third, assuming the EU does intend to push for reforms, what changes in its internal arrangements and external representation does it need to implement to be an effective player?

Section 2 of this paper presents the state of global governance, and section 3 discusses whether its malaise should be taken seriously. Section 4 is devoted to the role of the EU so far. Policy options for the future, recommendations and conclusions are proposed in section 5 .

\section{THE MALAISE ABOUT GLOBAL GOVERNANCE}

\section{The past 25 years: big changes, little reform}

In the last quarter century, the world economy has undergone profound changes. The global economy of the early $21^{\text {st }}$ century has little in common with that of the early 1980s, when a collection of integrating, but still highly segmented national economies coexisted with quasi-autarkic blocks (China, India, the Soviet Union and its satellites) representing about half the total world population. The world today has even less in common with the even more fragmented world of the early post-war period, when a few countries started 
rebuilding the world trade regime. Yet the global economic governance regime the set of global rules that govern international economic relations, the network of institutions that support and enforce those relations and the processes that steer change in this system - has not undergone a parallel transformation.

The changes that have taken place should certainly not be dismissed. The core institutions have taken up new roles - the IMF, for instance, has moved from financing current account deficits in the fixed exchange rate world of the early post-World War II decades to managing debt crises, marshalling the transition to the market and addressing financial account crises. Flexible responses to the transformation of the trade scene have been found through the creation of informal negotiation groupings within the WTO. Also, ad hoc structures such as the Financial Stability Forum have been created to steer cooperation between institutions.

But reforms have remained limited to adaptation and tinkering within the postwar system. On the face of it, the only significant institutional reform over the past 25 years was the creation of the World Trade Organisation (WTO) and its Dispute Settlement Mechanism in 1995. The other essential pillars of the postwar economic order - the UN system, the GATT, the Bretton Woods institutions - as well as the less-than-essential institutions have remained unchanged. The International Energy Agency, created after the first oil shock, has not undergone meaningful reform. It remains a consumers' cartel in front of a producers' cartel. In the Group of Seven (G7), first convened in 1975-1976, the key players remain the same narrow group. Both the addition of Russia in 1998 at head-ofstate level and the new habit of inviting other guests to G8 meetings have made only minor difference. Even the more significant creation of a Group of Twenty (G20) in 1999 based on the same model as the G7 (but only at finance ministers level) and the increasing role it has played have not challenged the overall steering role of the $\mathrm{G} 7$.

Attempts at more ambitious institutional reform have been rejected or have ended in failure. Grand schemes for creating new institutions outlined in the 1980 s and the 1990s, such as an Economic Security Council overseeing the specialised institutions, a Global Competition Authority, or a Global Bankruptcy Court, have never taken off. Even the more down-to-earth Multilateral Agreement on Investment negotiated in 1995-1998 within the OECD was eventually still-born. The attempted revamping of the IMF through the creation of a Sovereign Debt Resolution Mechanism (SDRM), proposed in 2001 by Anne Krueger, then the Fund's first deputy managing director, met the same fate. The handling of environmental issues offers a mixed record: Some technical agreements have met their goals, most remarkably the 1987 Montreal protocol on substances that deplete the ozone layer. However, the biggest environmental challenge, global warming, remains essentially unaddressed in spite of climate 
being the prime example of a global public good whose preservation must rest on international cooperation.

On the whole, considerable changes in the global economy have not been mirrored in the structure and missions of global institutions; and although institutions have adapted, there is a clear disconnect between economic and institutional developments.

It is, in a way, a remarkable tribute to the architects who were "present at the creation" of the post-war order - mostly US policymakers, and a few British ones - that the system they conceived sixty years ago has been able to serve a rapidly transforming world economy without major institutional reform. However, there are limits to the extent to which this flexibility allows the global governance system to adapt.

Against this background, two recent trends affecting the world economy are especially noteworthy. The first one is a threat of a nationalist resurgence. The second is the challenge of the rise of regional arrangements. We now turn to these, before exploring more fundamental causes of the malaise.

\section{The nationalist threat}

An obvious limit to global governance is the reluctance of individual governments to renounce sovereignty and accept collective decision-making. This is not new, but the landscape has been transformed as a consequence of several evolutions. To start with, there has been a change in US attitude. At the San Francisco conference in 1945, Harry Truman stated as US policy that "We have all to recognise, no matter how great our strength, that we must deny ourselves the licence to do always as we please". By contrast, a central theme of George W. Bush's re-election campaign in 2004 was that the US would not ask for a "permission slip" before taking decisions. Looking ahead, the US also seems to be hesitant as regards the potential role of global institutions in ensuring that the emergence of new global powers like China and India does not threaten its vital economic interests.

It may be debatable whether this apparent US drift is a key driver of what increasingly looks like a widespread revival of economic nationalism, or just a consequence of the same underlying causes. At least, it serves as an excuse: claims of 'economic patriotism' in France and similar attitudes in other European countries often cite US opposition on national security grounds to takeovers by CNOOC and Dubai Ports World as a meaningful precedent and as a justification for their own defensive proposals. 
The most profound shift may however be the emergence of new powers which have a different attitude towards multilateralism. Key economic players in the first decades after World War II were Europe and Japan, which had been recently traumatized by nationalist hubris. China, India or Brazil do not share the same historical experience and can easily perceive multilateral commitments as excessive constraints on policies inspired by national interest. Furthermore, in East Asia the traumatic experience of the financial crises of 1997-1998 has fuelled sentiment that the multilateral system cannot be trusted - hence the reliance on self-insurance through the building up of foreign exchange reserves.

Energy is another illustration. Since the fear of resource scarcity has reemerged, national governments in developed and developing countries have been busy securing access to oil fields through the strengthening of bilateral links with oil and gas producers. Despite emerging efforts to create an EU energy policy, the world has a long way to go before the need to ensure energy security can be taken up collectively rather than individually.

\section{The regional challenge}

There is a striking contrast between the relative immobility of the global governance system and the blossoming of regional initiatives. The evolution is well documented for trade, a field where all regional agreements have to be notified to the WTO. Since the WTO was created, about 130 such agreements have been reported, more than in the previous five decades taken together.

However, regionalism is by no means limited to trade. The EU is obviously much more than a trade block and its mere existence has profound consequences for all global institutions. Even in the absence of changes in European representation and participation in the governance of global institutions (we address this issue below), these institutions have started to take notice of the EU dimension. Interestingly, the IMF has recently decided to examine global imbalances "collectively with systemically important members and even with entities, such as regional groupings, that are not members" -- a clear recognition of the implications of the creation of a euro area within the EU.

Regionalism is alive on all continents, but most remarkably so in Asia. The advance of Asian regional integration is notable not only for its breadth but also for the fact that it is explicitly regarded by participants as an alternative to reliance on global institutions. At the time of the Asian crises in 1997-1998, the proposal for an Asian Monetary Fund was blocked by the G7 and countries in crisis were directed to the IMF instead. Since then, East Asian countries have been negotiating among themselves a series of regional monetary and financial cooperation agreements. To be sure, this cooperation has not been tested. 
Nevertheless, it is intended to provide a form of collective financial security at the regional level.

Regionalism, therefore, is a fact that cannot be simply ignored or opposed by the supporters of multilateralism.

\section{A CAUSE FOR CONCERN?}

Having described threats and challenges to multilateral governance, we now attempt to understand what are the underlying difficulties, whether apparent disaffection with global governance should be regarded as a serious concern, and whether there are substitutes for it.

\section{Why disaffection?}

Four underlying factors make the task of global governance increasingly demanding.

To start with, the diversity of preferences within the world economy has increased dramatically. Global governance traditionally involves a trade-off between economies of scale and differences in preferences. The more diverse countries are, the less they tend to agree on devolving policy responsibilities to a supranational entity. Yet beyond the increase in the number of players (Figure 1), differences in historical backgrounds and development levels are bound to result in differences in preferences. This simply increases the cost of agreeing on a common response and makes compromise on any subject much more difficult to reach, even when increased interdependence simultaneously increases the benefits of cooperation. In sum, "the multiplicity of countries, their divergent historical experiences and the differences in the quality of the regimes they live under [...] make it difficult to ensure the provision of global public goods"(Wolf, 2004). 
Figure 1 Number of countries taking part in multilateral trade negotiations.

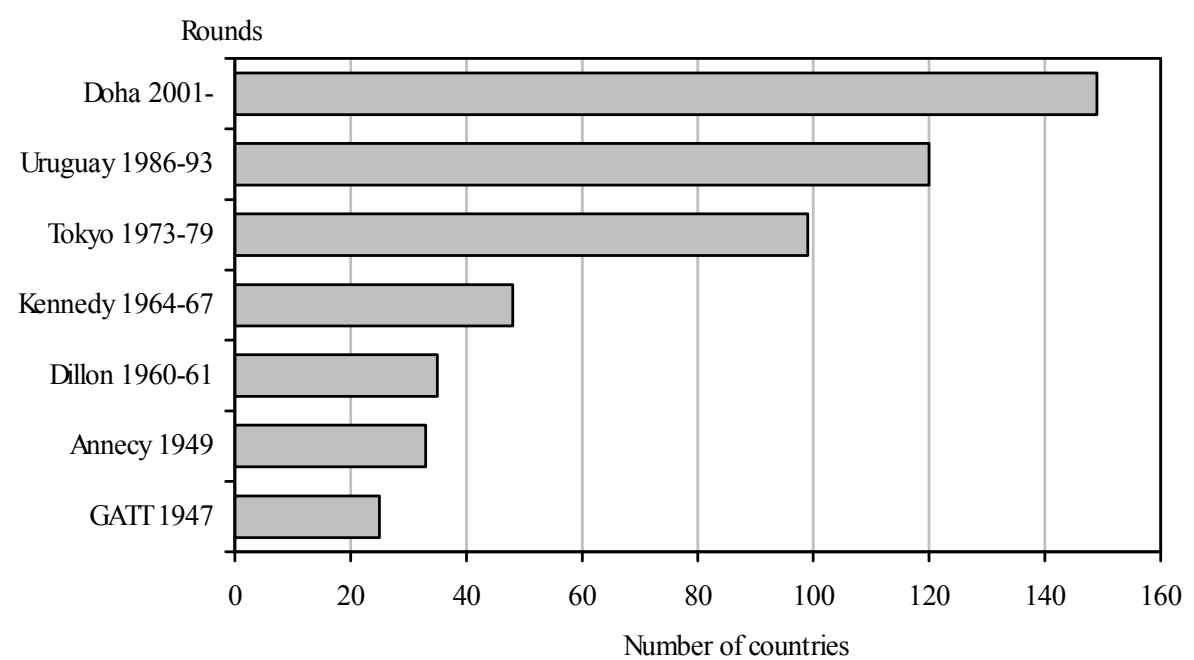

Source: WTO.

Second, among countries of unequal development level, many global issues involve an international distributional dimension that compounds the difficulty of reaching agreement. This is obviously the case for debt relief, but is true also for trade liberalisation, since countries benefiting from the preferential trade agreements in existence are bound to lose from an alignment of trade tariffs. This also applies to policies designed to tackle global environmental challenges, for which equity issues are compounded by the intertemporal dimension: the prime objection of emerging countries to curbing greenhouse gas emissions is that developed countries had a free ride on the global environment in the previous stages of their development. In principle, those obstacles can be addressed - at least for a transition period - through international redistribution. In fact, some redistribution is already taking place through development assistance and the asymmetric allocation of greenhouse emission quotas. However, the distributional problem remains extremely difficult to tackle unless a benevolent hegemon stands ready to internalise the problem and buy off opposition.

Third, globalisation is divisive within developed and developing societies. The extent of its contribution to the rise of within-countries inequality and job insecurity is disputed, but the most basic models of integration through trade, capital flows and migration point to distributional effects that create winners and losers. Furthermore, in many instances, global institutions are regarded as the source of globalisation itself and of its deleterious consequences, thereby weakening their political legitimacy. 
Fourth, and not least, the end of the Cold War has removed an powerful incentive to collective action. The change in the attitude of the United States, which is now more inclined to adopt a multi-track strategy that includes regional agreements and unilateral initiatives as alternatives to the multilateral route ${ }^{2}$, has probably less to do with economic factors than with political factors. Being now the world's biggest debtor, the US is certainly not in a neutral position on trade, exchange rates and global finance, but similar issues (though on a smaller scale) also arose at the time of the Bretton Woods system with the accumulation of dollar balances by European countries. It is true also that the US position in the world economy offers opportunities for regulatory leadership, but this again was even more the case in the past. On the political side, however, major shifts have taken place. US national security no longer calls for cementing an economic coalition of states in the same way that it did in the Cold War period. As scholars of international relations often say, the Cold War glue has gone. The so-called US "war on terror" justifies a targeted monitoring of financial flows and specific development assistance efforts. However, it does not require a system of economic alliances to bind countries together.

There are therefore structural factors behind the problems faced by global governance. The question becomes, can we dispense of global rules and institutions?

\section{Where is global governance needed?}

A deterioration of global governance may not in itself be a cause for alarm. Institutional arrangements, after all, are means, not ends. The world has already experienced periods of high international interdependence with no multilateral international order. This was especially true during the first wave of globalisation in the decades before 1914, a period when the concept of global governance had not been invented. The framework of world economic interdependence was provided by a set of universally accepted core principles (such as adherence to the Gold Standard and free capital mobility), a network of bilateral agreements (especially on trade), and political ties (especially between the imperial powers and their dominions). Globalisation's main driver, however, was the dynamism of private capital (Eichengreen 1996, Frieden 2006). Today's world shares many of these features.

To many practitioners, especially in the private sector, the value of an institution is what it is able to deliver. In this respect, the travails of multilateral trade negotiations have not prevented trade flows from expanding over the last ten years. Moreover, the absence of a multilateral framework for foreign direct

\footnotetext{
2 This is apparent in the document published by the White House on the national security strategy (US government, 2006). 
investment has not prevented strong growth in capital flows (Figure 2). Global governance is thus confronted with a necessariness problem.

Figure 2 World trade and foreign direct investment, 1980-2004.

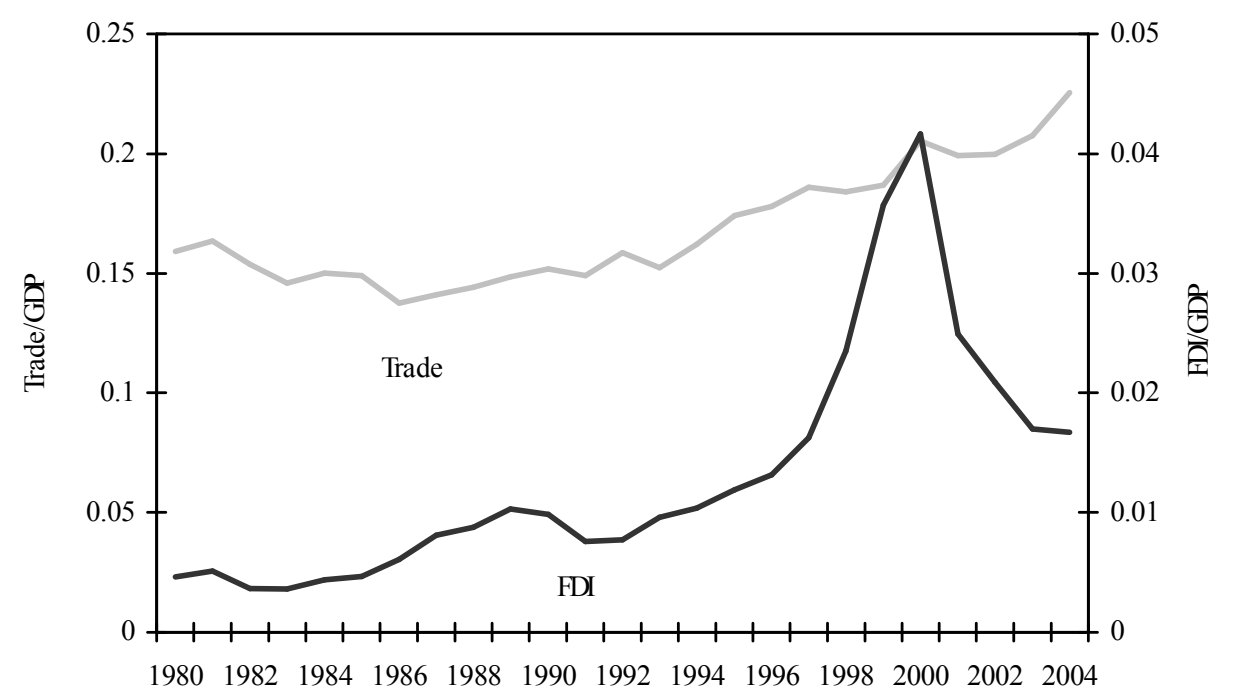

Source: Bruegel calculations based on international sources.

\section{Alternatives to global governance: national leadership}

There are furthermore potentially efficient substitutes for global governance. A first one is national leadership: Countries holding a dominant position may de facto set rules for the global economy. This is typically the case for standards, which multinational companies need to apply to have access to corresponding markets. For example, US Generally Accepted Accounting Principles (GAAP) are used by all US-listed companies and have therefore become a reference in many emerging markets such as Brazil and Israel, whose companies often list on the New York Stock Exchange or Nasdaq. Similarly, product safety requirements in the EU are demanding and tend to be adopted by manufacturers worldwide, including for products sold outside Europe, especially on matters over which the US has no corresponding regulation.

However, and notwithstanding issues of "hard" security which are outside the scope of this paper, such rule-making patterns based on the "benevolent hegemonism" of one player are often not sustained over the long term. The hegemon may succumb to the temptation of using its position to serve shortterm national interest and the followers may decide that their own interest is better served by alternative strategies. This is illustrated both by the recent tendency of many countries, including those of the EU, to endorse International 
Financial Reporting Standards (IFRS) as an alternative to US GAAP accounting rules, and by the growing unease in the US about EU-originated product regulation.

\section{Alternatives to global governance: market-based rulemaking}

Another substitute for governance by global public institutions is a similar function, but exercised by private-sector organisations. Markets have an ability to self-organize without the direct involvement of international institutions and are generally faster in designing and reforming arrangements. This is especially true of financial markets, which have always been the spearhead of international integration and have developed spectacularly in the past 25 years.

It is worth recalling that the widespread financial liberalisation of the last two decades has taken place without countries entering multilateral negotiations and taking on formal commitments, at least at a global level. While public institutions participate in the monitoring of financial fragilities, private rating agencies such as Standard \& Poor's and Moody's have established de facto global standards in the assessment of sovereign as well as private debts.

Private-sector global governance regimes are emerging as a significant component of global rule-making. The International Organisation for Standardisation (ISO, founded 1947), International Accounting Standards Board (IASB, founded 1973) or Internet Corporation for Assigned Names and Numbers (ICANN, founded 1998) are well-known examples. In addition, private initiative in development assistance is making inroads into the traditional domain of public institutions.

As expressed by Francis Fukuyama (2006), "The old realist model of international relations that sees the world exclusively organised around sovereign nation-states simply does not correspond to the world that is emerging, and it will not be sufficient to meet the needs of legitimacy and effectiveness in international action in the future. [...] Formal organisations acting on the basis of instructions that come up the accountability channels of sovereign states are too inefficient to suit the economic needs of the global economy. We have accepted a trade-off of legitimacy, transparency, and accountability for the sake of efficient decision making in the economic realm".

This does not need to be regarded as a threat to the multilateral system. Governance through multilateral institutions and rules can coexist with market self-organisation and can even find positive synergies with it. Yet this does represent a challenge as governments and institutions need to adapt to the emergence of new forms of governance. 


\section{A/ternatives to global governance: regionalism}

A last alternative is regional governance. Regional institutions among countries sharing similar preferences can be a solution to the problem created by differences in preferences, even when externalities are truly global. To the extent that the rules adopted at regional levels are mutually compatible and regional governing institutions are in dialogue with each other, the need for a global framework is reduced. International trade is an interesting case where the expansion of regional arrangements now seems to be overtaking multilateral rules. Competition policy is another example. There is no global competition authority. However, the decisions of European and American authorities have extraterritorial impact, and there is informal cooperation among them. Both authorities are careful to avoid situations of blatant inconsistency of their mutual doctrines, even though they may differ in individual cases such as the highprofile cases on GE-Honeywell or Microsoft.

Furthermore, the contrast between global and regional approaches is probably not as sharp as it is generally portrayed. The reason is that rarely, if at all, are international externalities either purely global or purely regional. To the extent that externalities are instead both regional and global, they need to be addressed both regionally and globally, rather than at only one level. How this is done in practice varies a great across subject matters.

Take the case of health. Today, all communicable diseases have a global dimension and require global solutions. At the same time, however, many communicable diseases have an important region-specific dimension. It makes sense, therefore, that the World Health Organisation (WHO) is in fact a network that comprises a global headquarters and six regional offices dispersed across the world, as well as national health institutions that are affiliated to both the global organisation and the respective regional body. What is remarkable is the balance between the regional and global components of the network, with roughly the same proportion of resources (personnel and budget) allocated to the six regional offices and the global headquarters in Geneva. Although the network aspect of the WHO is not entirely immune to problems, it certainly plays a crucial role in controlling the international spread of communicable diseases within and between regions.

There is no equivalent situation in the field of economic governance, though discussions on trade and IMF reform (Truman, 2006) have started taking the regional dimension into account. The IMF, the World Bank and the WTO have no regional office to which member countries are affiliated and which play an executive role. Nonetheless, some form of regional arrangement exists in each of the domains pertaining to these three organisations, but the relationship between regional arrangements and global institutions is weak at best. Only in 
the case of the WTO do the treaties foresee the possibility that member countries form regional groupings and insist that they respect certain rules in doing so. However, the rules have been so weak that only one of the 130 or so regional trade agreements (RTAs) notified to the WTO has actually been formally endorsed by the organisation. ${ }^{3}$ Even worse, the Committee on Regional Trade Agreements (CRTA), which is supposed to verify the WTO compliance of RTAs, has generally been unable to reach a conclusion "due to various political and legal difficulties" (see Crawford and Fiorentino, 2005). Whether or not the new Transparency Mechanism for RTAs agreed by WTO members in June 2006 will actually "help break the current logjam in the WTO on regional trade agreements...[and constitute] an important step towards ensuring that regional trade agreements become building blocks, not stumbling blocks to world trade" (Lamy, 2006) remains to be tested. In the meantime, the relationship between regional trade agreements and the spirit (if not the letter) of the WTO will remain tenuous.

The upshot is that there is probably less of a contradiction between multilateralism and regionalism than usually thought, but that their coexistence needs to be organised. How to design rules and institutions to this end is probably one of the major challenges for the years ahead.

\section{The cost of no governance}

Global governance should therefore neither be dismissed nor considered as the only possible way to manage economic globalisation.

The prime reason why it should not be dismissed is that there are issues that call for global collective action. This is obviously the case where there are high global externalities, such as for the global environment, global epidemics and global financial crises. In this respect, the current regime of global economic governance is incomplete in several important areas.

In a more subtle way, multilateral rules and institutions, though they may be painful to negotiate among a large number of countries with diverse domestic conditions, offer three advantages even when global externalities are only moderate.

First, they ensure more security than ad hoc arrangements. In time of stress or tension, rules provide core principles to which to refer and represent legally enforceable commitments. Moreover, institutions offer a venue for settling disputes. A comparison between trade and FDI may clarify the point: Global

3 This unique case is the customs union between the Czech Republic and the Slovak Republic set up after the break up of Czechoslovakia. 
trade is based on clear principles (such as national treatment and the mostfavoured-nation clause); the WTO treaty explicitly includes safeguard clauses and established a dispute settlement mechanism. All those elements are lacking for FDI. As a consequence, in the event of a dispute over a takeover, there can be no reference to universally accepted principles, no recourse to exceptional conditions, and no neutral venue for arbitration. This leaves the prevention of unilateral action and retaliation to the sole wisdom of the states.

In other words, strong rules and legitimate institutions may help to ensure the resilience of global economic integration. They are certainly no panacea and their ability to resist pressure should not be overestimated. However, in times of crisis and threats to economic integration, rules and institutions provide a valuable response.

Second, global institutions give a voice to all countries big and small and are accountable to these countries. Critics may complain about the distribution of votes and seats or about the lack of effective accountability, but global institutions ensure a degree of fairness and ownership which other solutions necessarily lack. This, also, is a contribution to the stability of economic integration. This stability, however fragile, would be lacking in a multipolar world in which integration would be driven by private initiatives only, without the legitimacy that is provided by global rules and institutions.

Third, institutions are a form of capital and can themselves be viewed as global public goods (Kindelberger, 1986). This is because established institutions which can rely on founding principles and internal governance rules can help tackling new issues as they emerge. They help cutting negotiation costs and avoiding the long and painful process of defining a collective response. Well-designed and well-governed institutions are therefore an asset for all participants in the world economy.

Yet like all public goods, global public goods are subject to the free rider problem since their benefits are available to everyone. Hence, although everyone would be better off if countries agreed to provide global public goods, it is normally in the interests of individual countries to let others bear the cost. The result is that global institutions are difficult to set up and difficult to maintain. The aftermath of World War II was an exceptional set of circumstances that served as a catalyst for building both the multilateral system and regional institutions in Europe. In Asia, the 1997-1998 financial crises seem to have played a similar, albeit more limited role. 


\section{The tasks ahead}

Summing up, the main challenge for the years ahead is to adapt the global governance system to the new global reality: a larger and more diverse set of countries; new priority such as migrations, climate change and energy security; geopolitical conditions that deeply differ from those of the previous decades; the rise of new powers with strong national sentiments; the irreversible development of regionalism; and changing borders between the realms of public regulations and market self-organisation. This will require initiative and leadership. We now turn to the question of what role Europe can play in such a process.

\section{THE EU AND GLOBAL GOVERNANCE}

If anything characterises Europeans' attitude towards global governance, it is ambiguity.

\section{A champion of global rules}

On the one hand, there is a natural synergy between an effective EU and an effective global governance regime. In international economics as elsewhere, the EU is the champion of rules (Laïdi, 2005). The reason for that is straightforward: Unlike most states which originated in unilateral conquest, the EU is itself a rules-based endeavour. The entire history of European integration since 1950 has been a patient but consistent attempt at rebuilding intraEuropean relations on the basis of a system of laws, rules and decision-making procedures. It is therefore quite natural for the EU to envisage international relations in the same way and to champion global governance. Hence, for example, the EU's active role in the creation of the International Criminal Court and the Kyoto protocol on global warming, both of which were rejected by the United States. Robert Kagan famously characterized Europe as being "from Venus" and as "moving beyond power into a self-contained world of laws and rules and transnational negotiation and cooperation" (Kagan, 2002). This may also be linked to the EU's possibilities to project power abroad. The EU has many means to exercise "soft power" internationally and is increasingly doing so. By contrast, the exercise of hard power by EU's members and partners generally tends to weaken the Union, as has been most graphically illustrated by the conflict in Iraq. The EU is naturally more comfortable in a world of procedures and negotiations, and would have much to lose from a deterioration of multilateralism. 
European public opinion is also very sensitive to the issue of globalisation and Europeans expect the EU to help "manage" globalisation. In a 2003 survey $^{4}$, $56 \%$ of EU15 respondents said that globalisation needed more regulation and $61 \%$ trusted the EU to ensure that globalisation went in the right direction. Europeans also consistently assign to the EU, rather than to the member states, responsibility for participating in global governance. For example, a recent survey indicates that $77 \%$ of respondents in the EU25 would like more decisions regarding the promotion of peace and democracy in the world to be taken at the EU level. The corresponding proportion is $72 \%$ for the protection of the environment and $70 \%$ for the prevention of major health problems ${ }^{5}$. The notion that there are global issues which can better be tackled by the EU than its member states seems to receive strong support among Europeans.

Finally, the Europeans have a major stake in the global governance regime. With the exceptions of the United Nations and the WTO, which are based on the onecountry-one-vote principle, most international institutions have an internal allocation of power that reflects the world of yesterday rather than today, and Europe is, nominally at least, the biggest beneficiary in this (Table 1). This is particularly true in the Bretton Woods institutions, where the EU controls about one-third of the seats and the voting rights, not an oversized share in reference to current GDP, but a clear overrepresentation by most other measures. As observed by Vijay Kelkar et al (2005), the combined votes of Brazil, China and India in the Bretton Woods institutions are about $20 \%$ below those of Italy, Belgium and the Netherlands, while their combined GDP at market exchange rates is $23 \%$ larger, their combined GDP at PPP exchange rates is four times larger, and their total population is 29 times larger. These are astonishing figures, which may explain why Asian countries feel so little ownership in the Bretton Woods institutions. The quota revision proposed by the IMF for adoption at its 2006 Singapore annual meeting does not change this overrepresentation in a significant way: it would reduce the EU share from $31.9 \%$ to $31.3 \%$.

Special Eurobarometer survey on globalisation, November 2003.

Eurobarometer survey on the future of Europe, May 2006. The survey did not include specific questions on the economic governance of globalisation. 
Table 1 Weight of the EU in international economic and financial institutions.

\begin{tabular}{|c|c|c|c|c|}
\hline \multirow[t]{2}{*}{ Institution } & Votes* & $\begin{array}{l}\text { Current-dollar } \\
\text { GDP } 2005\end{array}$ & $\begin{array}{l}\text { PPP-based } \\
\text { GDP } 2005\end{array}$ & Population \\
\hline & EU Share & EU Share & EU Share & EU Share \\
\hline G7** & $\begin{array}{c}57.1 \\
(4 \text { of } 7)\end{array}$ & 32.8 & 31.0 & 36.4 \\
\hline$G 8^{* *}$ & $\begin{array}{c}\mathbf{5 0 . 0} \\
(4 \text { of } 8)\end{array}$ & 31.9 & 29.2 & 30.3 \\
\hline G20** & $\begin{array}{c}25.0 \\
(5 \text { of } 20)\end{array}$ & 25.1 & 16.9 & 6.5 \\
\hline $\begin{array}{l}\quad \text { OECD } \\
\text { membership } \\
\text { financing }\end{array}$ & $\begin{array}{c}\mathbf{6 3 . 3} \\
\mathbf{3 9 . 8} \\
(19 \text { of } 30)\end{array}$ & 38.1 & 36.9 & 38.5 \\
\hline IEA & $\begin{array}{c}\mathbf{6 5 . 4} \\
(17 \text { of } 26)\end{array}$ & 38.3 & 36.9 & 39.8 \\
\hline $\begin{array}{l}\text { IMF/WB**** } \\
\text { membership } \\
\text { quotas } * * * * \\
\text { control } \\
\text { seats }\end{array}$ & $\begin{array}{c}\mathbf{1 3 . 6} \\
\mathbf{3 1 . 9} \\
\mathbf{3 3 . 6} \\
\mathbf{2 9 . 5} \\
(25 \text { of } 184)\end{array}$ & 30.3 & 21.0 & 7.2 \\
\hline WTO** & $\begin{array}{c}17.4 \\
(26 \text { of } 149)\end{array}$ & 31.7 & 22.6 & 8.1 \\
\hline $\begin{array}{l}\text { Memorandum: } \\
\qquad \mathbf{U N} \\
\text { membership } \\
\text { financing }\end{array}$ & $\begin{array}{c}\mathbf{1 3 . 0} \\
\mathbf{3 6 . 5} \\
(25 \text { of } 192)\end{array}$ & 30.3 & 20.9 & 7.2 \\
\hline
\end{tabular}

$\left.{ }^{*}\right)$ Figures in brackets refer to the number of EU members of the total number of members.

(**) The EU is not included in calculations for the G7 and G8 as they are not full members. The G20 has 19 members, plus the EU as an institutional member. In the WTO, the "European Communities" are counted as a separate member

$(* * *)$ For IMF and WB, "membership" gives the proportion of EU countries in total member countries, "votes" their share in the total quota-based votes, "control" the proportion of votes they control, assuming a country holding the chair controls the vote of the members in the constituency

$(* * * *)$ Before the quota revision tabled for the Singapore annual meeting

Source for GDP and population: World Development Indicators database, World Bank and The World Factbook, CIA, August 2006. 


\section{An accidental player}

That said, Europe's behaviour more than occasionally contradicts its stated goals and apparent interest in global governance. Although claiming to be a champion of multilateralism, the EU has in fact contributed toward challenging it by taking the initiative to negotiate a whole array of regional trade agreements. While all major players nowadays have developed a regional strategy alongside their participation in multilateral institutions, it is the EU which launched the trend (Sapir, 1998).

Moreover, the EU does not really play in global governance a role commensurate to its representation. The EU is undoubtedly a major player in international trade negotiations where it has clearly stated priorities and the ability to push for them. Whatever the negotiation setting, it is part in the game. The EU has also played a key role in the negotiation of the Kyoto protocol; after the US withdrawal, Europe has taken the leadership in pushing for ratification and implementation. However, the EU has kept a strikingly low profile on global macroeconomic issues. In stark contrast to the US, Europeans have not expressed any strong views so far on issues such as the unwinding of current account imbalances or the Chinese exchange rate. On the euro-dollar exchange rate, several mutually inconsistent opinions have been expressed by Europe's ministers of finance and central bank governors. On the nature and speed of the US current account adjustment, Europeans have more than once given the impression that their best hope is for a exchange rate stability, while routinely exhorting the US to fiscal discipline and a correction of the external deficit. On the Chinese exchange rate, Europe has tended to follow the US lead, although Europe's interest may differ substantially from that of the US. Euro area policymakers thus seem to have refrained from drawing conclusions from the new de facto world status of their currency.

On international finance, Europeans have certainly been part of the conversation within the G7, the G20, the Bretton Woods institutions and other public forums. They may even claim some successes, such as the partial reform of IMF governance through the creation of the International Monetary and Financial Committee (IMFC), or the so-called involvement of the private sector in crisis resolution. However, careful analysis of the discussion shows that Europeans have rarely set the agenda. They have often responded to new developments in a reactive manner, slowly adapting to events and adjusting to new (frequently US) proposals, and have almost never pushed for radical new ideas. The US behaved throughout the financial crises of the 1990s as the (most frequently, but not always, benevolent) hegemon of international finance. The EU did not 
behave as a world monetary and financial power ${ }^{6}$. Here again, the EU's effective role does not seem to be commensurate with its members' representation in the Bretton Woods organisations.

Rather than being a consistent pillar of world economic governance, the EU can thus be characterised as an accidental player (Pisani-Ferry, 2005) - one which, depending on the issue, is sometimes at the table and sometimes absent, sometimes vocal and sometimes silent.

\section{The root causes: incompatible views, or plain bad decision-making?}

Why is it so? The two main hypotheses to explain the EU's inconsistency in global economic governance are: (1) there are issues on which the EU is too divided to act, because preferences differ among its constituent member states, and (2) dysfunctional internal governance prevents the EU from being more assertive. If the first hypothesis is true, there is little the EU can do to become more effective. If it is the second, reforms of the internal governance are in order.

The preference heterogeneity argument has some weight. Within an increasingly diverse EU, there are many reasons why preferences should differ and this diversity should affect international economic relations. From cultural and policy traditions to degrees of openness and patterns of trade and financial integration, several factors can explain why the EU countries can have difficulties reaching common ground on global matters.

However, this is first and foremost true for international trade. From development levels and specialisation patterns to the functioning of labour markets and to domestic political institutions, there is every reason to consider that the economics and the political economy of trade liberalisation differ widely within the EU. Actually, surveys consistently indicate wide differences in public attitudes towards trade liberalisation within the EU. Despite these differences, the EU does have a common policy for trade.

This leads to the dysfunctional governance hypothesis. The EU has put in place complex and diverse arrangements for organising its international economic and

6 Riccardo Faini, a former Executive Director with the IMF, and Enzo Grilli (2004) have attempted to measure quantitatively the influence of the US, the EU and Japan in the IMF and World Bank decisions by assessing whether the geographical lending pattern of those institutions reflects their respective bilateral trade or financial relations patterns. Their results suggest that the US and the EU are both influential, but the former more so than the latter. They especially contrast the importance of both trade and financial links for the US with the absence of any discernable influence of the EU's financial links. This is an admittedly rather indirect measure that is subject to technical discussion, but it corresponds well to the casual observation that the US financial community is much more concerned by and vocal on IMF issues than its counterpart in Europe. 
financial relations with the rest of the world. In some fields, policy responsibility is fully delegated to an EU institution - in most cases, the Commission or the ECB - which has been given a clear mandate to act. In others, responsibility is divided between member states which may endeavour to coordinate their views. It could be the inefficiency of some of its governance mechanisms that prevents the EU from playing the role it could play.

\section{An illustration: the EU and the IMF}

Apart from being important in itself, the IMF provides an interesting testing ground. It is an institution where the EU is at the same time overrepresented in numbers and underrepresented in voice. According to Lorenzo Bini Smaghi, who prior to his appointment to the board of the European Central Bank was involved in the coordination of European positions in international monetary and financial affairs, "if EU countries wish to improve their collective influence in international issues and the IMF, some institutional changes in the way European interests are represented and promulgated may be necessary"(Bini Smaghi, 2004).

Moreover, for reasons already given a reform of the global economic and financial institutions that would rebalance power within them is not simply a matter of fairness; it is also a necessary (though not self-evidently sufficient) means to ensure a sufficient degree of ownership in the multilateral system by emerging countries. The EU has every interest in encouraging all countries to rely on the multilateral system. The more unbalanced this system, the stronger the temptation will be for those who feel underrepresented to look for alternative solutions, especially (but not only) in East Asia.

Pressure is mounting for a redistribution of power. The 2006 Singapore quota revision is explicitly regarded as a first step in a process that would lead, by 2008 , to a more substantial rebalancing. The US administration has unambiguously expressed its support for this rebalancing. Europeans, however, are tempted to procrastinate. Among them, the question of a common representation remains divisive.

The IMF voting structure allows us to compare various arrangements in terms of power, using the standard game theory indices that measure a player's power by how frequently he is likely to be the swing voter in a decision. True enough, there are very few instances in which IMF executive directors actually vote. But the underlying power structure serves as a benchmark against which players measure their influence. The fierce controversies associated with each quota rebalancing are a clear indication that the issue matters a great deal.

In a recent paper, Lorenzo Bini Smaghi (2006) finds that, if they were to form a coalition, the EU- 25 member countries would be, by far, the dominant power in 
the IMF with a voting power index of $48 \%$ - the next one being the US with $7 \%$. An important issue, however, is whether individual member states would gain or lose from entering such a coalition.

On the face of it, they would all gain considerably. Suppose that EU countries decide to pool their votes in a single European seat and that this seat is granted the same voting power as the United States (not an unreasonable assumption in view of the quota formula and the balance of power within the Fund). Further assume that the internal EU decision is determined by simple majority voting using the current IMF weights. Under these conditions, calculation by Leech and Leech (2005), based on power index methodology ${ }^{7}$, shows that all EU countries would gain voting power in the IMF (Figure 3 ).

Figure 3 EU countries voting power with an EU caucus relative to current voting power within IMF.

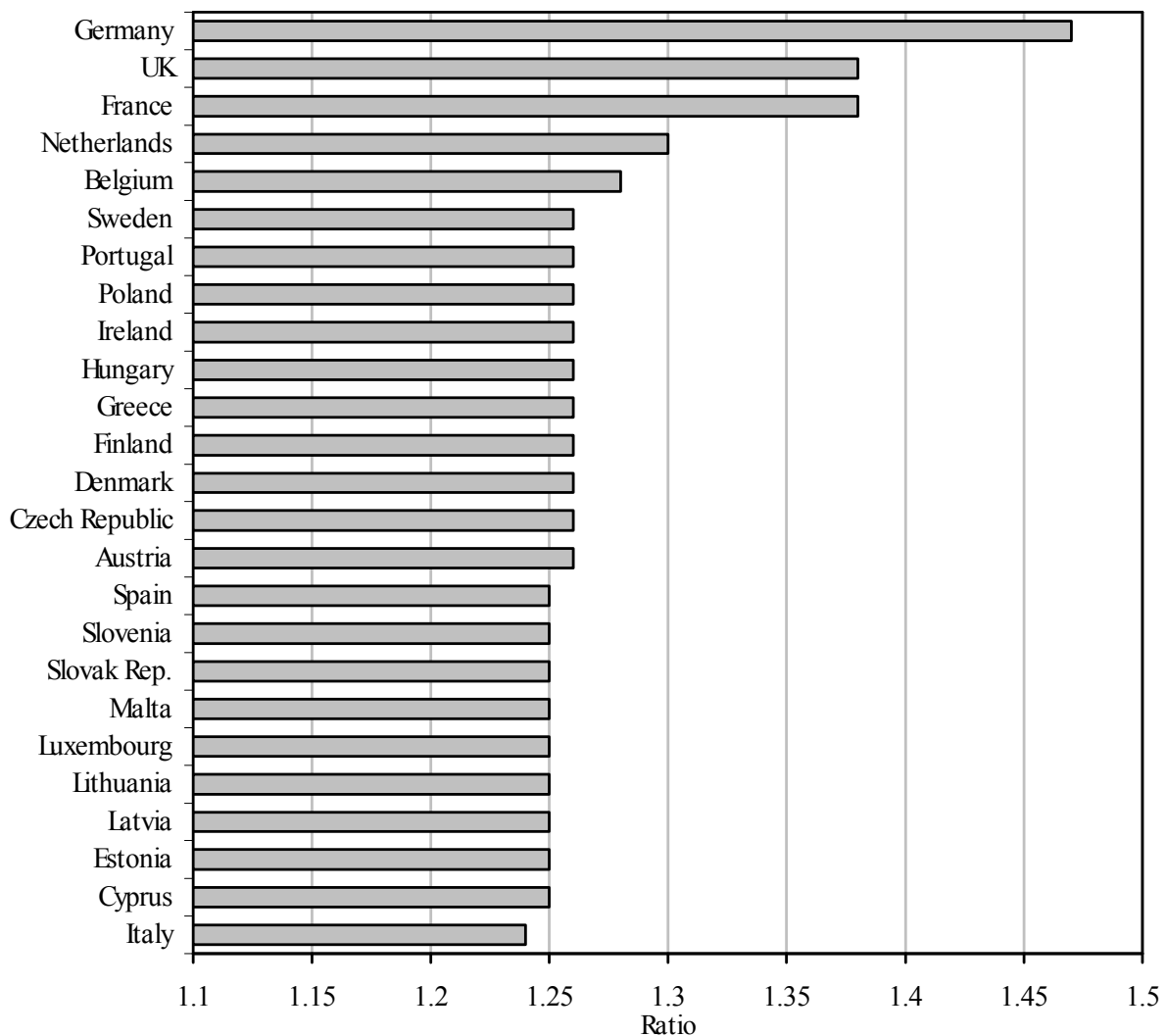

Source: Leech and Leech (2005).

7 Formally, the power index for any EU member is calculated as a product of two Penrose indicies, one measuring the power of the single EU seat and the other measuring the power of the member in the internal EU decision making. 
However, IMF quotas substantially differ from EU voting weights and a common representation of the EU would use EU weights and voting rules, rather than IMF quotas or votes. This raises the issue of power redistribution among EU countries. As shown in Figure 4, merging EU members' representation in the IMF based on EU voting rules would create both winners (Poland, Spain and the smaller countries whose vote counts more within the EU) and losers (Germany, the UK and France, as well as some medium-sized ones such as Belgium and the Netherlands). The extent of this redistribution is significant because the current (Nice) EU voting system ${ }^{8}$ is much more biased in favour of small countries than the IMF system.

Figure 4 Voting weights in EU relative to voting weights among EU countries in IMF.

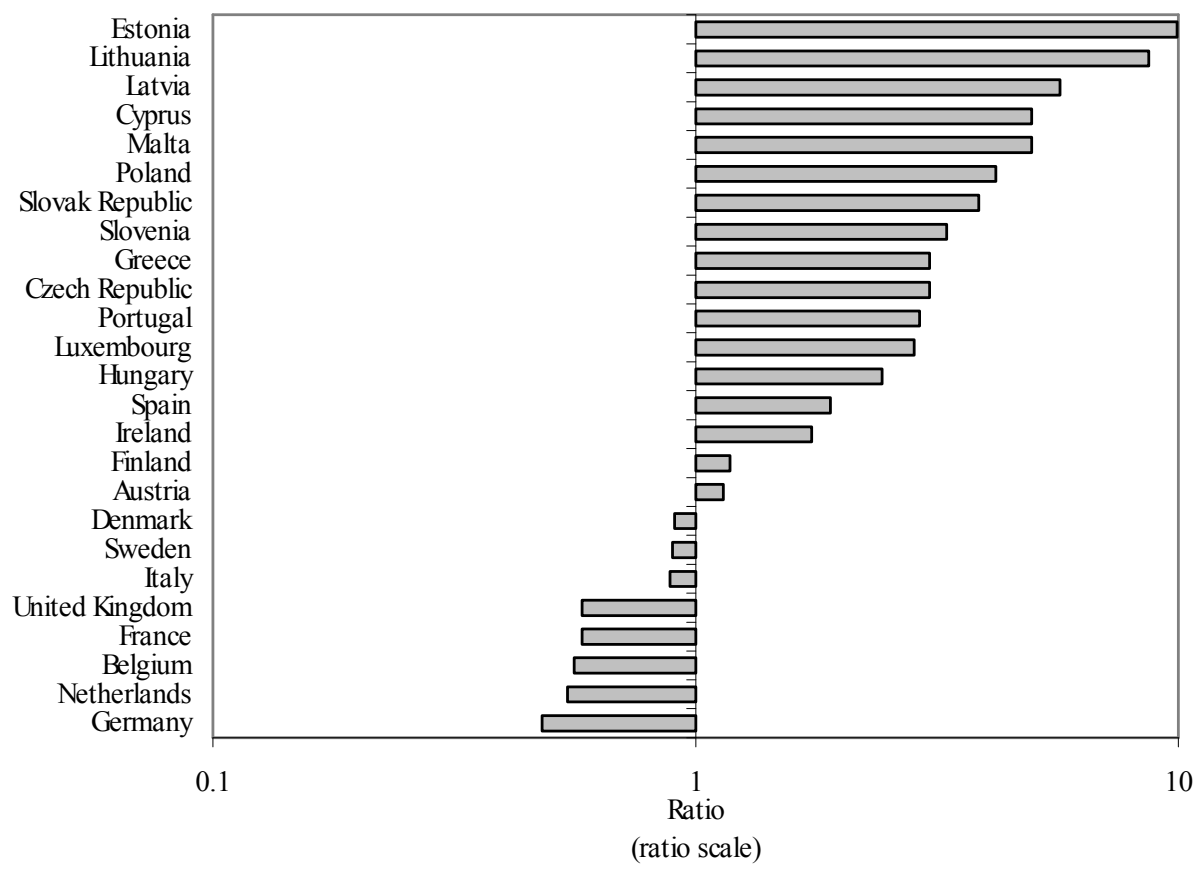

Source: Bruegel estimates.

This picture however overlooks the fact that a member's voting weight is not the same as its voting power. The distinction is crucial. An individual EU member's power in the IMF under a unified representation would depend on both a member's power to determine the EU vote in the IMF and on the aggregate voting power of the single EU seat - which could in theory make all countries winners, even though the size of the gain would not be uniform.

8 The draft constitution retained a similar system. 
However, there would actually be more losers in this move since internal EU decision would need to be determined by the notoriously inefficient system of qualified majority voting established by the Nice Treaty (Figure 5). This is because the large supermajorities required to make a decision under the Nice system would in fact prevent the EU from benefiting from its power within the Fund. The largest countries would logically be the biggest losers.

The calculations presented here should not be taken at face value. What they indicate is that the large countries would lose power in the IMF on issues where the EU is internally divided. They would still gain, however, on issues where there is a clear majority opinion within Europe. Two conclusions can nevertheless be drawn from this analysis. The first is that internal governance matters considerably and that the EU's role in global governance cannot be discussed without reference to it. This lends support to the hypothesis that Europe's sometimes haphazard behaviour in international fora is due to its internal rules.

Figure 5 EU countries voting power with an EU chair (Nice voting system) relative to current voting power within the IMF.

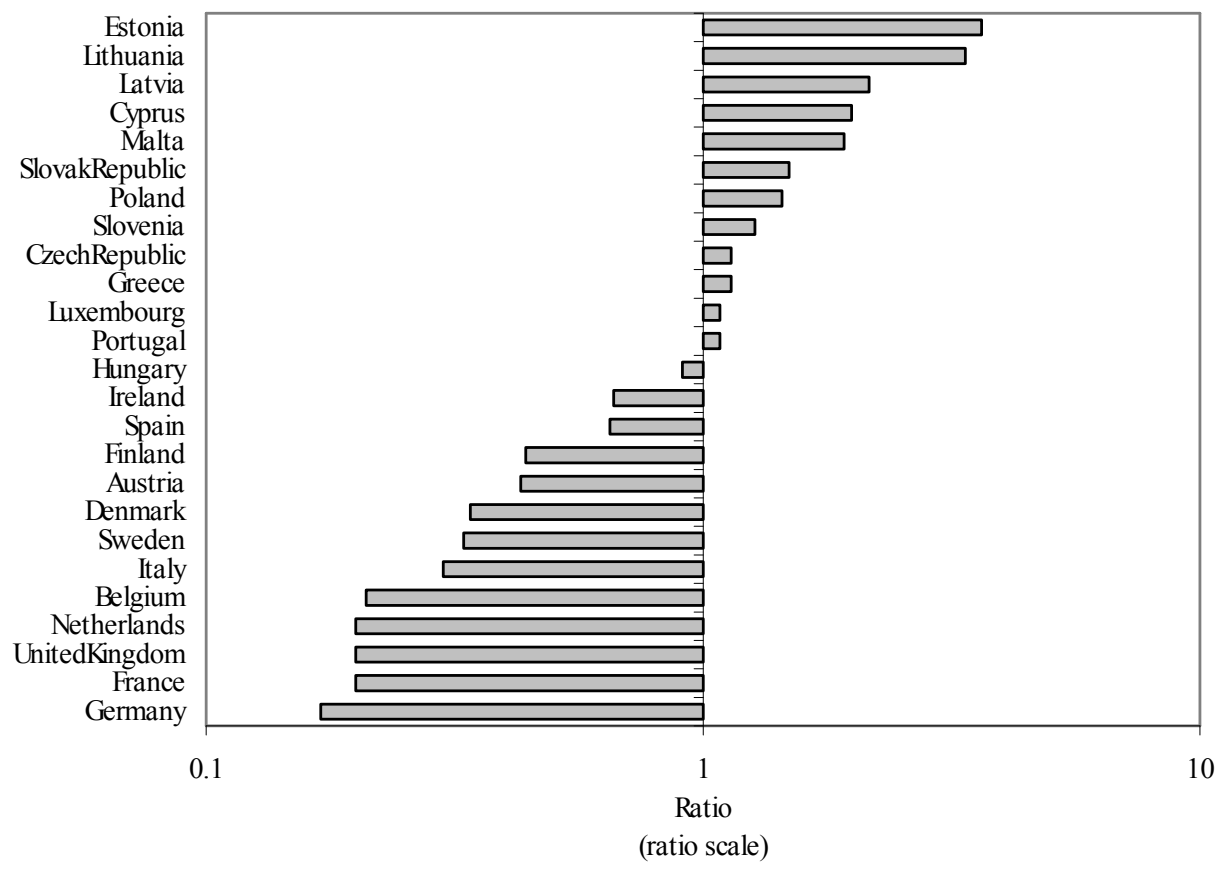

Source: Leech and Leech (2005). 
The second conclusion regards the Bretton Woods institutions. The perspective of losing influence through both a reduction of voting weights in the IMF and, possibly, the merger of European representations, can serve as a justification for defending the status quo. Procrastination, however, would be a costly mistake. Europe's share in world GDP is rapidly declining as a consequence of its demography and of the accelerated development of major emerging countries. It is bound to decline further - and fast. In institutions, however, compromises on power-sharing tend to be lasting and to perpetuate a certain distribution of power long after it has disappeared in the real world. The more the adjustment is delayed, the less economic and political weight Europe will have when it takes place, and the less likely it is to be able to negotiate a satisfactory arrangement.

\section{IMPLICATIONS FOR EUROPE}

This paper has argued that because the state of global economic governance is anything but stable, the European Union needs more clarity of vision for the debates ahead. The policy implications of our analysis can be summarized into three main points.

1. Global economic governance matters. There could be a sense that the apparent loss of purpose of many global institutions - the UN deemed 'irrelevant' by the US, the World Bank squeezed out by the private sector, the drying up of IMF lending activity, the WTO negotiations stalled without a clear prospect of revival - is not a matter of significant concern. After all, security issues are dealt with outside the UN, the expansion of financial markets is welcome, emerging markets are becoming more stable, and international trade is booming, to name a few examples.

However, downplaying the importance of global institutions would be a costly mistake. While some missions of global institutions have indeed been rendered obsolete, others are more crucial than ever in the current age of unprecedented economic interdependence. The long-term sustainability of current trade patterns is heavily dependent on a functioning multilateral framework. Financial stability problems will again arise, and the IMF remains the best available tool to monitor and prevent the corresponding risks. Furthermore, global institutions can be extremely helpful in times of crisis as they provide ready-made channels for communication and coordination.

The absence of global economic institutions in certain areas is also a source of concern. Problems which call for new forms of global economic governance are becoming ever larger, and disaster might loom if they remain unaddressed. This is most prominently the case for the economic mechanisms to prevent and address global warming. The problem of global 
natural resources (including fossil fuel and water) is also increasingly likely to require attention.

2. Reform is needed. A first obvious area for action is on trade, where regionalism is both a fact and a natural response to the diversity of preferences in the world economy. But for regionalism to support rather than undermine multilateralism, principles need to be agreed and safeguards need to be defined. Being itself the archetype of a strong and successful regional grouping, the EU ought to constructively contribute to this conversation.

The Bretton Woods institutions are another immediate area for reform. EU member states should be proactive in specifying a mandate for the EU as a catalyst for reform of the IMF's and World Bank's governance. This is a necessary (if not sufficient) condition to ensure the legitimacy of these institutions, which have played a helpful and important role in the past and will do so again in the future.

Third, Europeans should see it as their responsibility to ensure the emergence of a globally shared approach to address the causes and consequences of global warming. It is becoming increasingly obvious that the EU's adhesion to the Kyoto Protocal is not enough to face the challenges of climate change.

Beyond these steps, it could be argued that there is a need for a more political institution that defines priorities and steers institutional changes when needed. The G7, which accounts for about $40 \%$ of world GDP and $10 \%$ of world population, no longer has the legitimacy to fulfil this function ${ }^{9}$. Various proposals have been made, including the creation of a G20 at headof-state level (accounting for about $80 \%$ of world GDP and $60 \%$ of world population $)^{10}$. However, it remains to be seen how far such a device could go in creating a genuine prospect for collective action given the diversity of the participants.

3. External influence requires efficient internal governance. In particular, the ability of the EU to act as a global player is often hampered by inefficient internal arrangements. This should not be read as a plea for federalisation of external representation. Member states can retain control rights through the definition of a mandate and the supervision of its implementation. But the reform of the EU's external representation requires

9 Measured at purchasing-power parity exchange rates.

10 See Linn and Bradford (2006). Kenen, Shafer, Wicks and Wyplosz (2004) propose instead the creation of a Council for International Financial and Economic Cooperation of at most 15 members. 
a definition of the ways in which various national views are mediated and the external representatives are monitored. There would be no point in aiming at more external influence while at the same time preventing it from existing because of an internal inability to reach decision.

4. The European Union can no longer hide behind the US. For the economic and political reasons that have been developed in this paper, the US is less ready than at any time since World War II to exercise constructive leadership in global economic governance, and this trend is unlikely to be reversed any time soon. European policymakers should be ready to assume the responsibilities that shifting patterns of leadership may imply for them. 


\section{REFERENCES}

Bini Smaghi, Lorenzo (2004), "A Single EU Seat in the IMF?", Journal of Common Market Studies vol. $42 \mathrm{n}^{\circ} 2$.

Bini Smaghi, Lorenzo (2006), "IMF Governance and the Political Economy of a Consolidated European Seat", in Edwin Truman (ed), Reforming the IMF in the XXIst Century, Institute for International Economics.

Eichengreen, Barry (1996), Globalizing Capital, Princeton University Press

Faini, Riccardo, and Enzo Grilli (2004), "Who Runs the IFIs?", CEPR Discussion paper n 4666, October.

Frieden, Jeffry (2006), Global Capitalism: Its Fall and Rise in the Twentieth Century, Norton.

Fukuyama, Francis (2006), America at the Crossroads, Yale University Press.

Kagan, Robert (2002), "Power and Weakness", Policy Review ${ }^{\circ} 113$.

Kelkar, Vijay , Praveen K. Chaudhry, Marta Vanduzer-Snow, and V. Bhaskar (2005), "The International Monetary Fund: Integration and Democratization in the 21st Century", paper presented to the March G24 Technical Group Meeting, Manila, the Philippines.

Kenen, Peter, Jeffrey Shafer, Nigel Wicks and Charles Wyplosz (2004), International Economic and Financial Cooperation: New Issues, New Actors, New Responses, Geneva Reports on the World Economy n6, ICMB-CEPR.

Kindelberger, Charles (1986), "International Public Goods without International Government", American Economic Review vol. 76 n¹, pp. 1-13.

Laïdi, Zaki (2005), La norme sans la force: l'énigme de la puissance européenne. Presses de Sciences Po, Paris.

Lamy, Pascal (2004), La démocratie-monde, Paris : République des Idées / Seuil

Leech, Dennis, and Robert Leech (2005), "Voting Power Implications of a Unified European Representation at the IMF", Warwick Economic Research Papers, Number 720, January.

Linn, Johannes and Colin Bradford (2006), Pragmatic Reform of Global Governance: Creating an L20 Summit Forum, Policy Brief 152, The Brookings Institution: Washington, DC.

Nye, Joseph (2002), The Paradox of American Power, Oxford.

Pisani-Ferry, Jean (2005), The Accidental Player: The EU and the Global Economy, Lecture at the Indian Council for International Economic Relations, www.bruegel.org

Sapir, André (1998), "The Political Economy of EC Regionalism", European Economic Review 42, pp. 717-732.

Truman, Edwin (2006), "Overview of IMF Reform", in Edwin Truman (ed), Reforming the IMF in the XXIst Century, Institute for International Economics.

US government (2006), The National Security strategy of the United States.

Wolf, Martin (2004), One Economy, Many States: The Political Economy of Globalisation, Thirteenth Annual IEA Hayek Memorial Lecture, Institute for Economic Affairs, London. 